\title{
Fences in the borderland:
} technique, landscape and the architectures of domestication in the Brazilian-Uruguayan Pampa

\author{
Caetano Sordi ${ }^{1}$ \\ 'Instituto do Patrimônio Histórico e Artístico Nacional (IPHAN), Porto Alegre/RS, Brasil
}

\begin{abstract}
Recent perspectives on domestication have emphasized the importance of technical objects and other environmental elements as mediators of the relations between humans, animals and the many landscapes they inhabit. Using the concept of "architecture of domestication", proposed by Anderson and others (2017), this article investigates the role of alambrados (wire and wooden fences) in the context of animal husbandry in the Brazilian-Uruguayan Pampa, the technical processes involved in their construction, as well as the new configurations and uses for these structures that have emerged along with the biological invasion of European wild boars (Sus scrofa) in the region. I will show that the alambrados are key elements in the difference between positive direct action and negative indirect action in relation to the animals of the herd within the Pampeano system of domestication.
\end{abstract}

Key Words: Domestication; Animal Husbandry; Fences; Wild Boar; Pampas. 


\section{Cercas na fronteira: técnica, paisagem e as arquiteturas da domesticação no Pampa brasileiro-uruguaio}

\section{Resumo}

Recentes perspectivas sobre domesticação têm enfatizado a importância dos objetos técnicos e demais elementos ambientais como mediadores das relações entre humanos, animais e as diferentes paisagens que habitam. A partir do conceito de "arquitetura da domesticação", proposto por Anderson e colegas (2017), examino neste artigo o papel exercido pelas cercas de arame e madeira (alambrados) no contexto pecuário do Pampa brasileiro-uruguaio, os processos técnicos envolvidos em sua construção, bem como as novas configurações e usos para estas estruturas que emergem em face ao processo de invasão biológica conduzido por javalis asselvajados europeus (Sus scrofa) nesta região. Viso demonstrar, por fim, que os alambrados são peças-chave na dialética entre modos diretos positivos e indiretos negativos de relação com os animais de rebanho no sistema domesticatório pampeano.

Palavras-chave: Domesticação; Pecuária; Cercas; Javali; Pampa. 


\title{
Fences in the borderland:
}

\section{technique, landscape and the architectures of domestication in the Brazilian-Uruguayan Pampa}

\author{
Caetano Sordi
}

\section{Introduction}

Extending from the confluence of Quaraí and Uruguay rivers to the mouth of the Chuí stream, the border between Brazil and Uruguay extends for some $1000 \mathrm{~km}$ in a northwest-southeast direction. Much of this border is "dry"; that is, it is not marked by watercourses or by any major topographical features. Thus, in the zone between the so-called Rincão de Artigas ${ }^{1}$ and the Aceguá/Aceguá international conurbation, there is a prevalence of rolling prairies that, in his Facundo: Or, Civilization and Barbarism (1895), the writer (and later Argentinian president) Domingo F. Sarmiento referred to as "the image of the sea upon the land; the earth as it appears upon the map" (Sarmiento 2010: 72).

Indeed, anyone who travels through the back roads of the interior of the Ibirapuitã Environmental Protection Area - the only federal conservation unit in the Brazilian Pampa, situated precisely along this tract of the border (fig. 1) $)^{2}$ - is frequently possessed by this feeling of vastness and infinity, particularly in those early morning hours when a fog makes it difficult to discern the horizon, the limits of the land and the beginning of the sky. The succession of rolling plains confers on the landscape of the Pampa, or the Campanha, a maritime rhythm, often described as tedious or monotonous, an image expressed in Sarmiento's analogy and which reverberates in writings of more recent Rioplatense authors. The Argentine essayist Ezequiel Martínez Estrada (2017: 18-19), for example, wrote of "the amplitude of the horizon, which always looks the same as we advance [...], gives the impression of something illusory in this crude reality of the field". It would be easy, in this context, to lose track of the depth of the terrain, were it not for the omnipresence of another important element in the Pampeano landscape: the fences of straight or barbed wire known as alambrados or aramados ${ }^{3}$, which, arranged in straight lines throughout the field, provide a peculiar and comforting sense of perspective.

\footnotetext{
1 Rincão de Artigas is the name of the interfluve of the Quaraí River and the Invernada Creek. Along with the so-called 'Brazilian Island', located on the Uruguay River, it is one of the only disputed areas in in the border.

2 This conservation unit was created by presidential decree in 1992. It is made up of over 316,00o hectares divided between the rural zone of four municipalities of the state of Rio Grande do Sul: Santana do Livramento, Rosário do Sul, Alegrete and Quaraí. Its territory is made up of small, medium and large properties, mostly used for extensive animal herding. It is administered by the Chico Mendes Institute for Bio-Preservation (Instituto Chico Mendes de Preservação da Biodiversidade (ICMBio)), an agency linked to the Brazilian Ministry for the Environment. 


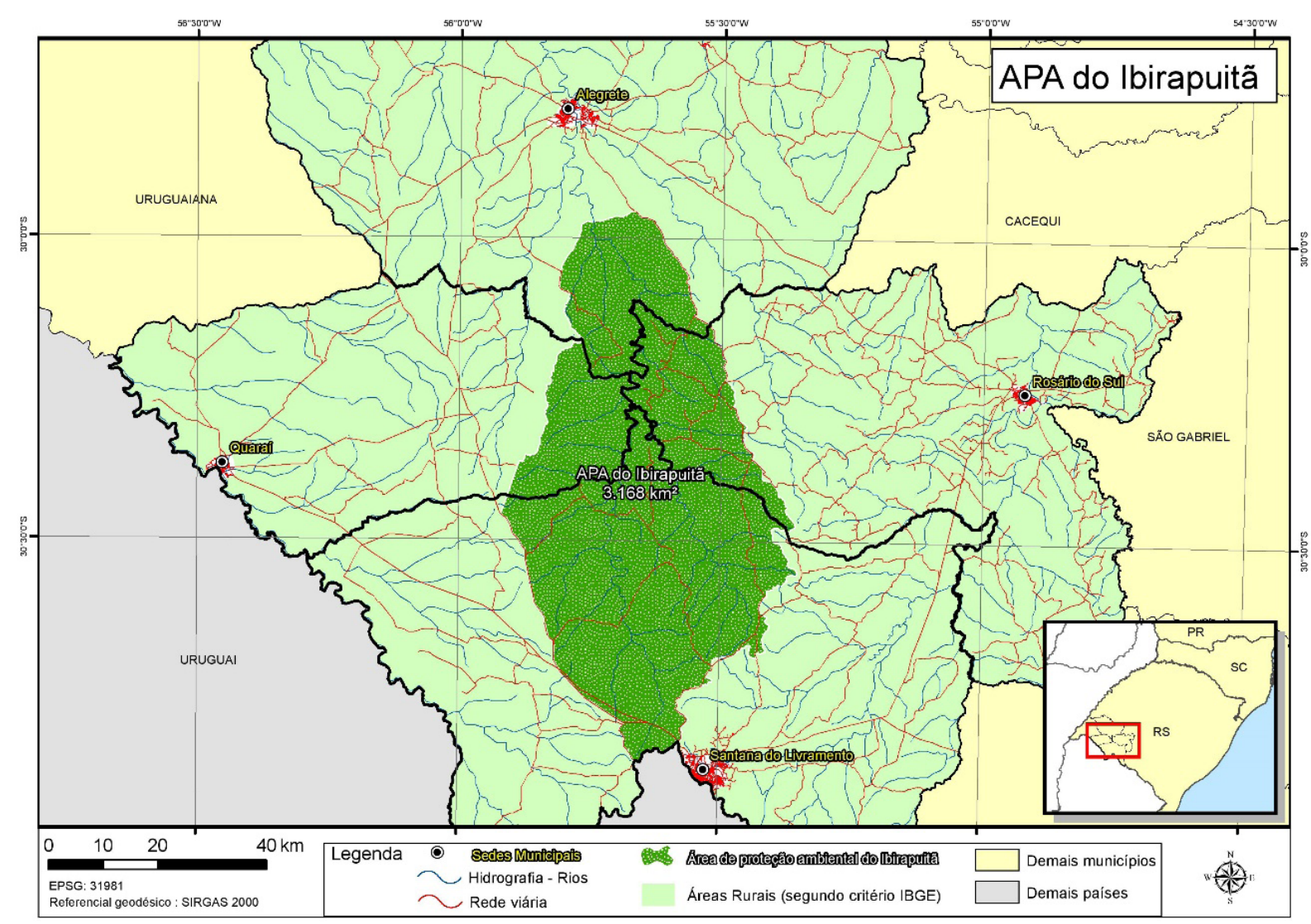

Figure 1: Map of the field site. Dark green area: Ibirapuitã Environmental Protection Area. Light green area: surrounding rural areas (cf. Brazilian Institute of Geography and Statistics/IBGE) belonging to the Santana do Livramento, Quaraí, Rosário do Sul and Alegrete municipalities. Yellow area: Other municipalities in Rio Grande do Sul, Brazil. Grey area: Uruguayan territory Blue lines: water courses. Red lines: roads.

Map by: Victor Ricardini.

Traditionally erected by people possessing a wisdom passed down through generations of a family lineage, alambrados divide properties from one another, and also delimit areas within each property, such as grazing land for cattle (invernadas), large corrals for branding and castrating animals (mangueiras), as well as domestic areas used by bosses or employees, and the main residential area. According to local knowledge, a good alambrado can last up to a century, depending on the expertise of the builder, and the diligence and persistence of those who care for it. Furthermore, along the so-called 'international corridor", the extensive dirt road that follows the dry tract of the borderline, alambrados can also divide sovereign territories, purportedly preventing herds from one country from mixing with those of another. Everyone knows that this is not always effective. As a zone of intense legal and paralegal exchange, the prototypical crime along the Brazil-Uruguay border is cattle raiding, or abigeato, the most common evidence of which is the damaged alambrados, along with slaughtered livestock left behind as an affront to their former owner.

In this article I will discuss the role of these fences in what we might call, following Anderson and his colleagues (2017), "architectures of domestication", which configure relations between human and nonhuman agents in the Pampeano landscape. These authors propose that a closer look at the structures that inscribe human-animal relations within a territory enables us to overcome certain structuring dichotomies in the debate on domestication, including the one that underscores the very definition of domestication as a 'domination/submission' or as a 'collaboration/symbiosis' (see also Russell 2007 and Stépanoff and Vigne 2019). In other words, through an analysis of these physical structures and their agentive potentialities, we can 
better understand the oscillation between "cultures of control" and "cultures of reciprocity" (Anderson 2014) that supposedly permeate different systems of domestication, moving beyond the focus usually afforded to one or the other relational modality.

This perspective, as I see it, converges with that of other contemporary researchers who have underscored the ethnographic importance of technical objects and material infrastructures in mediating interactions between humans and nonhumans (Sautchuk 2016; Segata 2017; Stoeckli 2017), as well as that between the landscape and its surrounding medium as aspects of the process of domestication (Ingold 2000; Leach 2007; Wilson 2007; Stépanoff e Vigne 2019). Finally, my approach in this article is also inspired by authors linked to the Maussian anthropology of techniques tradition (Akrich 1987; Lemonnier 2012; Descola 2002), which focus on the indissolubility of technical, social and political processes, endowing technical objects, their patterns of manufacture, use and selection, with great heuristical value for the social sciences in general.

For Lemonnier (2012: 119), in particular, an ethnographical interest in technical objects stems from their capacity to communicate, non-verbally, "key values or key characteristics of particular social relations that are usually hidden, although they pervade everyday life". Thus, technical objects act as "perissological resonators" of the social relations in which they are embedded, reiterating them ${ }^{4}$ and stabilizing them in a concrete or material sense. In light of this, we must ask: what social and power relations are condensed in the apparently banal Pampeano alambrado? What can its structure, disposition, manufacture and use tell us about the human and more-than-human dynamic that composes the border landscapes?

To answer these questions, I will first describe the process through which the alambrados emerged in the Pampeano landscape through two temporal registers. The first is a "phylogenetic" register, so to speak, which will reconstruct the historical macroprocess of fencing fields in the Pampas, and of structuring large grazing properties as the socioeconomic base of the Rioplatense region. The second, "ontogenetic" register, will describe the process of constructing a traditional alambrado, revealing the operational sequences and the labour relations involved in the craft of the alambrador. I will then explore the role played by the fences in the relational game that involves humans and herd animals in the Pampas, understanding them as material resonators (Lemonnier 2012) of the oscillation between positive direct and negative indirect (Haudricourt 1962) modes of domestication. In the conclusion I will discuss how recent transformations in the Pampeano environment, in particular the biological invasion of wild European boars (Sus scrofa) and their mating patterns with domestic pigs, have reconfigured the affordances (Gibson 1979; Reed 1988; Ingold 200o) of the alambrados, conferring new uses and potentialities on old material structures.

\section{Phylogenesis of the alambrado: from the smooth field to the chequered landscape}

To understand the meaning and emergence of the alambrados in the Pampeano landscape we must first reconstitute the history of its establishment as a political and pastoral frontier. Before European colonization, the territory that now makes up the south of the Brazilian state of Rio Grande do Sul, Uruguay and the northeastern Argentine provinces, was inhabited by various ethnic groups, most of them living exclusively by hunting and gathering, such as the Minuanos and Charruas. The Guarani, in contrast, were manioc cultivators who also collected yerba mate (Ilex paraguariensis), the consumption of which is arguably the most enduring contribution of these peoples to the culture of the Plata River valley and adjacent regions.

Starting in the 16th century, Spaniards from the Society of Jesus established reduction missions to settle and convert the Indigenous people of the region. Their establishment is coterminous with the introduction of European cattle and the creation of extensive breeding grounds for feral animals, known as vacarias

4 The term "perissological" conveys this sense of redundancy and reiteration. Lemonnier (2012) takes this idea from an analysis of non-linguistic elements in ritual, the engagement of which reiterates, non-verbally, the values cultivated throughout the ritual. 
(Osório 2006; Farinatti 2007). A way of life based on the predation of feral herds which reproduced freely in the prairies was thus established during the first two centuries of Iberian colonization. Initially, livelihood was based on the commercialization of leather in the plaza-forts of Spanish colonization along the Prata River. Later, Portuguese explorers penetrated the Pampeano territory, seeking both animal prey and Indigenous captives to be sold in the mining centres of the Brazilian southeast.

Ownership of land and animals only became stable in the Pampas, conforming to what Ingold (1980) would classify as a 'ranching economy's, after several border treaties were signed between the Portuguese and Spanish crowns during the long and troubled period that extends from the Guarani War (1753-1756) to the national independences at the start of the $19^{\text {th }}$ century ${ }^{6}$. This later cycle of pastoral development, which spans the period from the mid- $18^{\text {th }}$ century to the second half of the $19^{\text {th }}$ century, sees the emergence of the productive unit known as the estancia: the large rural property with feudal overtones that moulded the structure of land ownership in the region, as well as its sociocultural imagination, until the present.

This period also saw the first stone fences, known as taipas, many of which were constructed by African slaves (Osório 2006; Farinatti 2007)7. More than boundaries for rural properties, these stones protected the agricultural areas of the estâncias from animal intrusion, and delimited corrals and domestic perimeters. At the time, the predominant productive structure was based on shared grazing land used by the herds of the estancieiros (legitimate land owners) and their agregados, that is, the small breeders and free occupants tied to a lordship through bonds of clientelism. According to Xavier (1964: 58):

The free worker - the agregado and the peon - is employed in rural work under the direct supervision of the estancieiro or his foreman. The campeiro ${ }^{8}$ and his family occupy tracts of land, where he builds his ranch, plants and harvests his produce for his own consumption. The enjoyment of these benefits is dependent on his fidelity to the owner of the land. Some foremen or more capable and useful agregados receive animals - terneiros - during branding, as a reward for their services and their interest in the work.

In the absence of precise limits marked on the landscape, the limits of properties were in most cases defined by natural features (embankments or watercourses), or occasionally by stone markers that carried the insignia of the estancieiro, that same used to brand his animals (fig. 2). In the collective memory of the region, the period prior to the alambrados has mythical and nostalgic hues, as we can read in the prelude to a short story by the Rio Grande do Sul writer João Simões Lopes Neto (1976: 28):

Everything was open; the estâncias touched each other without fence or siding; the divisions of each was written in the papers of the sesmarias ${ }^{9}$; and maybe one estancieiro or another would place stone marks on the lines, when a pilot would show up, who knew the business and was suitably backed.

\footnotetext{
5 According to Ingold (1980), rancher economies are characterized by the establishment of property relations over both animals and land. In the pastoralist model, in contrast, property relations only concern herds, with grazing land being used communally.

6 The United Provinces of the Plata River, the embryo of the modern Republic of Argentina, declared their independence in 1810. Brazil became independent from Portugal in 1822. Uruguay separated from the Empire of Brazil in 1828. The Guarani War involved the Guarani against an alliance of the two Iberian crowns. Under the command of the mythical figure of chief Sepé Tiaraju, the mission Indians contested the borders established by the Treaty of Madrid (1750), which handed the Eastern Missions (currently the northwest of Rio Grande do Sul) to the Portuguese Crown (Golin 1999; Neumann 200o).

7 Xavier (1964: 58) points out that the estância mixed two types of work regime, which he classified as "natural economy" and "mercantile economy": the former results from the work of slaves, and are associated with harvesting, domestic work and domestic industries. The latter is developed from the work of freemen, with clientelist characteristics that are increasingly emphasised".

8 A synonym for gaúcho, rural livestock rearer.

9 The sesmaria was a Portuguese juridical institute that oversaw and ratified the occupation of land in the colonies. The first estâncias of the Brazilian Pampa were constituted from this system of land distribution. In the region that concerns us, most of the seismeiros were made up of veterans of the border wars who received a portion of the conquered land.
} 


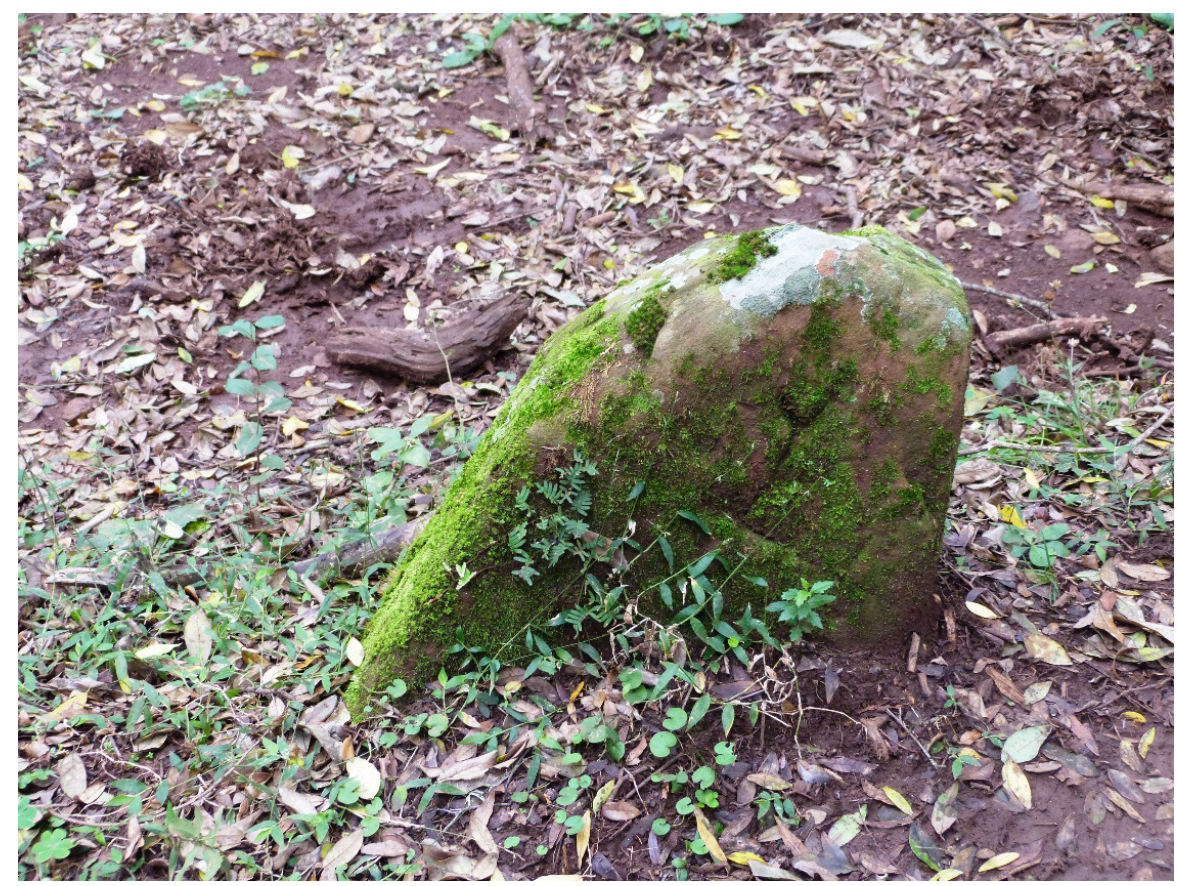

Figure 2: ancient stone marker of the São Marcos Estância, Rosário do Sul (Rio Grande do Sul, Brazil), May 2014. Note the figure etched on the stone, the same brand used on animals. Photo by the author.

This was the time of the great horseback incursions to gather feral cattle, separating them according to the brand of their respective owners (campereadas). While there is no doubt a certain Romantic exaggeration in recurring qualifications of this work as a "diversion", it is important to observe that these undertakings were part of a labour identity anchored on the founding experience of confronting a wild animal, which has ample reverberations in local notions of masculinity and honour.

For the Uruguayan anthropologist Maria Fernanda de Torres Álvarez (2011: 157), this breeding system, with its poorly delimited wide open fields, is at the origin of a cosmology native to the inhabitants of the region which she calls a "cosmology of smoothness", disdainful of the sedentarism of agriculture, and in which "the extensive fields, which looked the same for over a century, had instilled slow processes of variation and the conservation of places in memory". Inspired by Ingold (2011), and Deleuze and Guattari (1997), she argues that the modernization projects developed in her country after the middle of the 19th century always sought to tear up the native field with the civilizing virtues of agriculture, exorcizing it of the nomadic, violent and wild ethos usually associated with traditional pastoralism (Beretta and Markoff 1978; Giles and Gefu 1990).

Indeed, the ideological process to which Álvarez refers can be generalized to the three countries that make up the South American Pampas, the elites of which have always sought ways to develop and domesticate the landscape and its inhabitants, or, as I have suggested elsewhere, to "capture its feral-becoming" (Sordi 2017; 2015). It is in this context that the alambrados first appear, in tune with pressures to increase pastoral profit (mainly by introducing new breeds) and to 'modernize' productive relations in the countryside.

In the Brazilian case, the chequering of the prairies, by means of physical barriers to the flux of animals and men, gains favour with the 1850 Law of Lands (Farinatti 2007; Da Ros 2012). In Argentina, the introduction of wire fencing in the $19^{\text {th }}$ century resulted in peasant uprisings led by groups of gaúchos who did not accept the new terms of land ownership (Beretta and Markoff 1978). In Uruguay, Nahum (1968) points out that the alambrados are associated with what he calls the "woolly revolution" of the second half of the $19^{\text {th }}$ century, in which properties increasingly took up sheep farming as their main activity, looking to explore the international market in fibres. 
In terms of labour, fencing led to the intensification of the campeira workforce, which was definitively transformed into a rural proletariat. It also resulted in increasing tensions between "traditional" ways of dealing with animals, closer to patterns of hunting and capturing, and "rational" or "modern" ways, advocated by zootechnicians and rural land owners interested in increasing production through the incorporation of imported technology (Bornholdt 2016; Nahum 1968). According to Pereira et al. (2016: 198), due to the changes introduced by fencing:

Some estâncias gradually worked exclusively with fattening calves, other kept the full cycle of breeding and commercialization of animals, others mixed the two systems. There are estâncias where pastoralism is extensive, and others which have adopted the Voisin system, which is characteristic in that 'in this case, it is the bull who chases after the man and not the man who chases after the bull', and in which the horse is mostly absent; and there are those that mix the two models. The greatest difficulty, according to those land owners who have tried to adopt the Voisin system, concerns finding a suitable workforce for this sort of pastoralism, because most peasants do not adapt to work without the lasso and horse, without the need to violently dominate cattle: it is the traditional treatment of animals that employees miss most.

Another socially perverse effect of fencing has been the concentration of land ownership and the expulsion of occupants from common lands, which furthered rural flight and the formation of peripheral belts of unemployment or semi-employment in the border towns. Finally, fencing has also had negative ecological effects, leading to over-grazing and degrading the capacity for renewal of much of the natural grazing land, since estancieiros were forced to increase the number of animals per hectare to ensure a profit (Cruz and Guadagnin 2010).

According to Akrich (1987: 209), "one of the first operations carried out by a technical object is to define actors and a space". She argues that this dispositive capacity of technical objects - in the very sense of disposing, organizing an ensemble of things - reveals its intrinsic political component, insofar as they are key elements in the stabilization of relations among humans and between humans and the environment. Applying these considerations to the phylogeny of the alambrados in the Pampeano landscape, we may conclude that their emergence reconfigured the formerly given relations between humans and animals by scheming in the replacement of the capture of free-range cattle by an increasingly intensive and technical form of husbandry; and those among humans, by consolidating relations between employees and employers through dichotomies such as honour/distrust, discipline/liberty, protection/precariousness, which continue to characterize these relations to this day. But how is an alambrado raised? Who are the subjects tasked with building them? Which knowledge and technical expertise is mustered every time a new fence is built?

\section{Ontogenesis of an alambrado: the craft of the alambrador and its operational sequence}

Having reconstructed the sociohistorical phylogenesis of the alambrados that chequer the southern prairies, I will now turn to the process of creating the structure itself, its ontogenesis as a technical object. To this end, I will focus on the craftsmen that constitute it, the alambradores ('fence-makers') and their work. Like other craftwork typical of the Pampas, the work of the alambardor is usually characterized as being 'arduous' - very hard work, riddled with setbacks and difficulties. Raising kilometres and kilometres of fencing across vast fields requires many days' work, as well as exhausting travel, often in dreadful weather. In the Pampas, summers are torrid and winters are cold, submitting men and beasts to constant tests of physical endurance.

Alambradores are not generally employees of the estâncias, but itinerant workers who sell their trade via temporary contracts with landowners. In this they are similar to sheep shearers, known as esquiladores, who, during the height of wool production in Rio Grande do Sul and Uruguay, also had a similar work regime. 
Both professions are in the wane, due to the new technologies increasingly present in rural properties, the disinterest of younger generations in campeiro trades and, more widely, the chronic crisis of southern livestock breeding, where pastures have been suppressed and substituted by agricultural and agro-forestry monocultures. ${ }^{10}$

A lot of the time they are called to work, alambradores go to properties only to fix stretches of fencing damaged by people, animals or simply by the natural wear and tear of decades of use. Sometimes, however, they are asked to set up new divisions, for which they are paid higher wages, and which often also involve bringing down older fencing. After everything has been arranged with the landowner, the team of alambradores starts to work. The terrain, the soil, the topography and hydrology are all surveyed with care, since one of the greatest virtues of an alambrado - for which it is valued by those who commissioned it - is its ability to set a straight and steady line across a surface that is not always regular or receptive to geometric lines. Great value is thus place on how each line of wire is stretched out. A common analogy compares the alambrado to the strings of a finely tuned guitar.

Veteran alambradores tend to align the fences "by sight" ( $a$ olho), a skill they credit to accumulated experience and to transmission from fathers and grandfathers. According to a renown alambrador from Alegrete, theirs is not a task that one "learns in a rural school", but by "doing and building". In the countryside of the Ibirapuitã Area, with its predominantly basaltic soils, there is an additional challenge: to break through the stone and set the palanques, the hardwood stakes that support the structure. The preferred wood for the stakes is guajuvira (Patagonula americana L.) and angico (Anadenathera sp.), procured and carved in the forested areas of the properties. Recently, Australian eucalyptus (Eucalyptus sp.), an exotic tree which is widely distributed throughout the Pampa, has also been used.

The most important palanque is the esquineiro, placed where two stretches of fence meet at a right angle, which is where the wires are tied and stretched. To set it, a hole three palmos deep (around $70 \mathrm{~cm}$ ) must be dug. The stake is set in the hole, where it is kept stable by an aide known as the 'pillow' (travisseiro). The travisseiro is a piece of wood, somewhat smaller than the palanques, placed horizontally near the base of the esquineiro, where it is buried at about $10 \mathrm{~cm}$ depth.

A common supporting structure is the so-called duplo canto ('double corner') composed of a palanque mestre ('master stake') and contramestre ('foreman'), trava ('lock'), morto ('dead') and rabicho ('tiny tail'). The palanque mestres and the contramestres are installed at a short distance from each other, and they are joined at the top by the trava. A ditch is then dug next to the palanque mestre where the morto is inserted - the morto is a large-gauge wooden stump on which the rabicho is set. The latter is a reinforced weave of various lines of wire which, when extended diagonally form the morto to the juncture of the trava and the contramestre keeps the latter secured to the palanque mestre (Fig. 2).

\footnotetext{
10 As I noted elsewhere (Sordi 2017), the population of the municipalities that compose the Ibirapuitã Area - Santa do Livramento, Alegrete, Quaraí and Rosário do Sul - has declined sharply in the last few decades. Furthermore, despite their regional identity being anchored in the campeira mystique, their rates of urbanization are very high. The countryside is increasingly considered "empty", which is reflected in the complaint of rural landowners about the lack of a suitable workforce.
} 


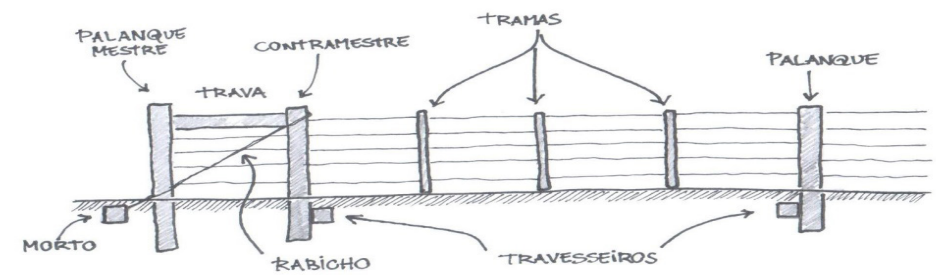

Figure 3: simplified model of an alambrado with double corners and its constituent parts. Elaborated by the author

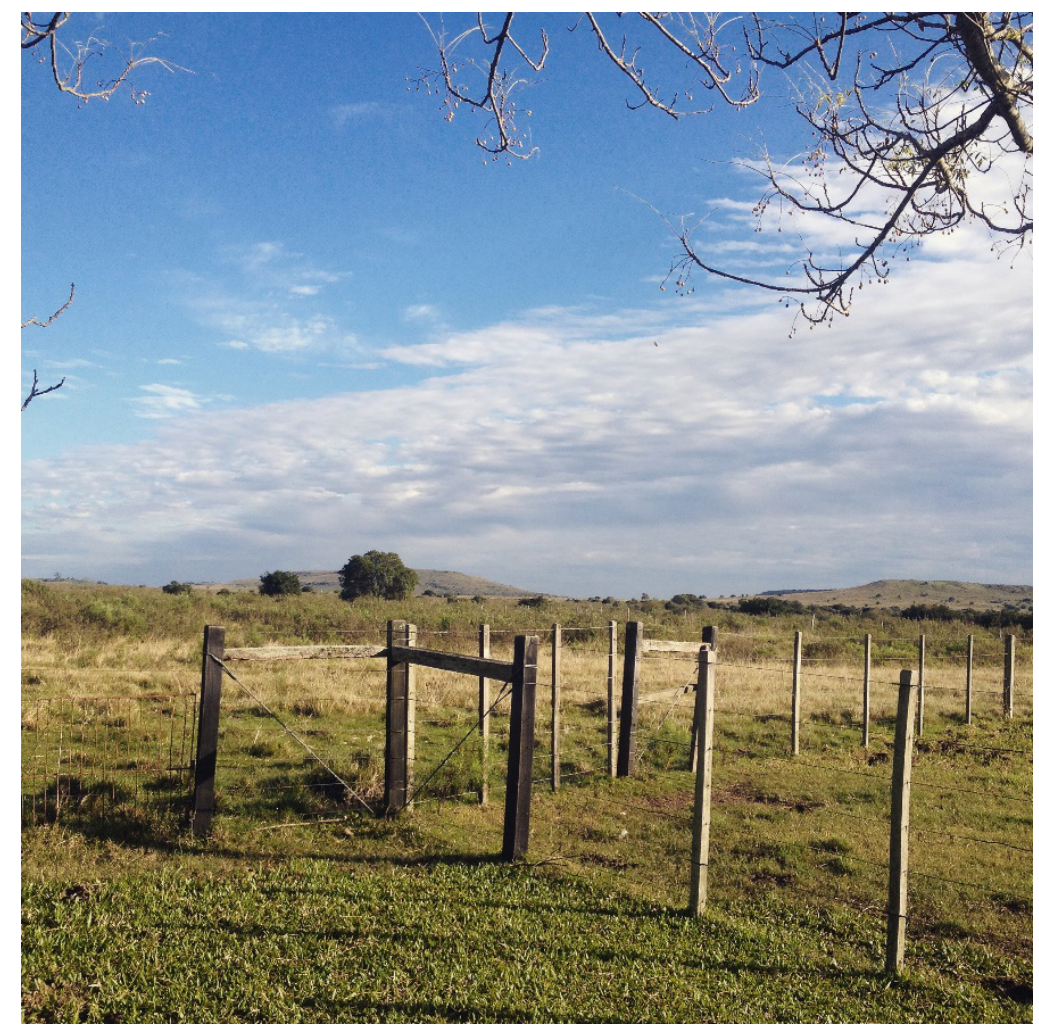

Figure 4: traditional alambrado with cantos duplos (double corners), Estância Renascença, Santana do Livramento (Rio Grande do Sul, Brazil), May 2016. Photo by the author. 


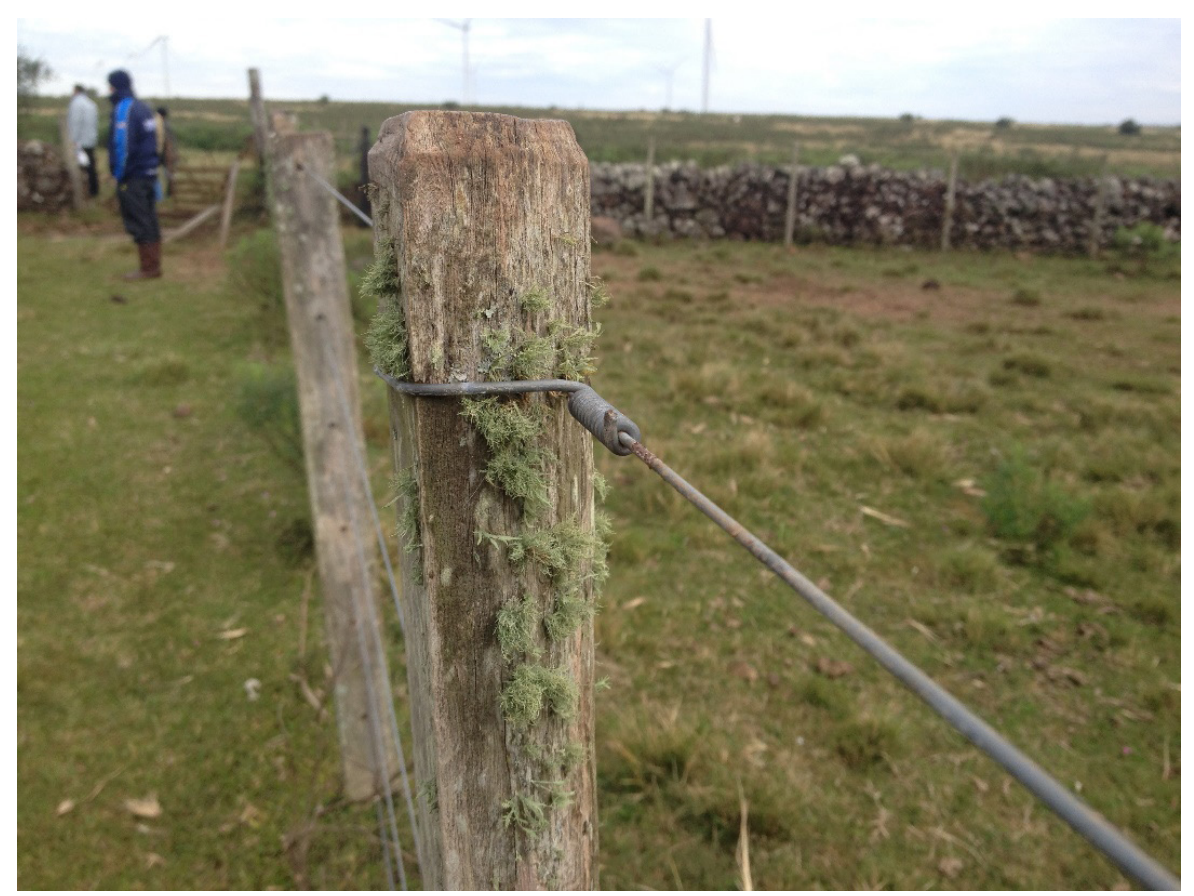

Figure 5: Detail of a palanque. In the background we see the remains of a stone fence. Estância Renascença, Santana do Livramento (Rio Grande do Sul, Brazil). May 2016. Photo by the author.

When the corners are installed, the other palanques are fastened to the fence at a distance of 7 to 10 metres one from the other. The space that is thereby created is then filled with the tramas, slightly thinner, but equally hardy, pieces of wood, laid out in sets of four. Both the palanques and the tramas are previously perforated with a manual or electric drill to allow the passage of the wires, which cross them all until they reach the palanque mestre or esquineiro.

The number of wires in an alambrado varies from four to seven. Due to the prevalence of sheep farming in the Ibirapuitã zone, seven-wire alambrados are more common. Three men working at a regular rate can dismantle one thousand metres of old alambrado and raise one thousand metres of new alambrado within a week. This all varies, however, with the vagaries of weather, and the famously unpredictable atmospheric conditions of the Pampeano region.

In an hour, teams of alambradores set up camp next to the fence that they are building, and they move as their work progresses. As with other Pampeano craft, the tie between alambradores and those who hire them is always narrated and conceived in terms of honour and trust. Bornholdt $(2010,2016)$, however, observes that this way of construing matters tends to conceal the low wages and the almost complete absence of any sort of formal labour guarantee. As a bargaining tool, many alambradores recall the old bosses and their unfettered generosity - old bosses who are often the direct ancestors (fathers or grandfathers) of the landowner with whom they are negotiating. The success of this manoeuvre is nonetheless increasingly slight, which obliges the few itinerant alambradores left to conform to the conditions imposed by their hirers.

Furthermore, it is ironic that many alambradores today live in the precarious peripheral belts of border cities, which have largely resulted from rural flight, itself historically catalysed by fenced fields. In the 2000 census, the municipality of Santana do Livramento had 90,849 inhabitants; in 2010 it had 82,464 inhabitants. This is one of the highest rates of depopulation in Rio Grande do Sul. Equally indicative is the fact that, although Santana do Livramento is the second largest municipality in the state, only $9,78 \%$ of its population lives in rural areas, a rate that is similar to the municipalities of Rosário do Sul (12,11\%), Alegrete (10,38\%) and Quarai $(7,43 \%)$. In all of them, the percentage of people living in rural areas falls below the average for the state $(14,9 \%)$ (Brasil 2000, 2010). 


\section{The alambrados and the architecture of domestication in the Pampa: between the control and autonomy of animals}

We must now turn in greater detail to the role of the alambrados in the architecture of domestication that sustains the relations between humans and herd animals and landscape in the Brazilian-Uruguayan Pampa. In his classic article Domestication des animaux, culture des plantes et traitement d'autrui, Haudricourt (1962) proposes that we distinguish between the domestication systems of the Mediterranean and the Far East through the difference between "positive direct action" and "negative indirect action". While western breeding regimes are characterized by the constant intervention and management of the movement and vital cycles of animals by the herdsman, the horticultural model prevalent in East Asia is based on the creation of favourable environmental conditions so that other living beings can develop according to their own rhythm.

More recent perspectives, however, have revealed that a great range of ways of relating can be maintained within the same context of domestication. For Stépanoff and Vigne (2019:10), domestication "is not a homogenous reality but a variety of ongoing interconnected biological and social transformations which extend through a continuum of interactions between control and autonomy". Anderson et al (2017) argue that different configurations of shared space between humans and non-humans enable mutual engagements that very often contradict one another, so that a corral or a cage can be interpreted both as dispotifs of control over animals, or as means of approximation and familiarization.

In agreement with what Anderson (2014) claims in an earlier article on reindeer herding in the circumpolar north, I propose that the skills required for herding work in the Pampas constantly shift between "cultures of reciprocity" (based on preserving the autonomy of animal agency) and "cultures of domination" (based on the imposition of human will upon other living beings). In other words, those who deal with animals in the Pampa develop skills that pertain both to the domination of and direct control over animals, and to their indirect management based on the manipulation of the affordances (Gibson 1979; Reed 1988) of the surrounding environment so that certain patterns of movement can be facilitated while others are avoided.

In this way, the alambrados play an important part in the indirect organization of animals, mainly by establishing the limits of grazing. It is worth recalling what Gell (1996) has to say about structures such as cages and traps: they are "surrogate hunters"; that is, material extensions of their cynegetic intentionality and working models of their venatic skills:

Once a trap is in being, the hunter's skill and knowledge are truly located in the trap, in objectified form, otherwise the trap would not work. This objective knowledge would survive even the death of the hunter himself. It would also be (partially) readable to others who had only the trap, and not the animal lore that was reflected in its design. From the form of the trap, the dispositions of the intended victim could be deduced. In this sense, traps can be regarded as texts on animal behavior. The trap is therefore both a model of its creator, the hunter, and a model of its victim, the prey animal (idem: 27 ).

We may say something similar of the alambrados in a herding context. While in a model of positive direct action it is up to the peão, with the aid of dog and horse, to conduct and guide the movement of the herds, in a model of negative indirect action this function is delegated to the alambardos, which, in its material constitution, incorporates and “resonates" (in Lemonnier's (2012) sense) rural workers' knowledge of the Umwelt of animals. Figure 5 illustrates some of this process. It shows two peões conducting a troop of cattle along a rural road (corredor) in the interior of the Ibirapuitã Area, delimited by alambrados on both sides. This scene depicts an interaction between positive direct means of dealing with the herd, embodied in the act of conducting the troop on horseback, with a lasso and a whip; and negative indirect modes of relating to the same herd, inscribed in the landscape as restrictions on the autonomous movement of animals afforded by the fences. 


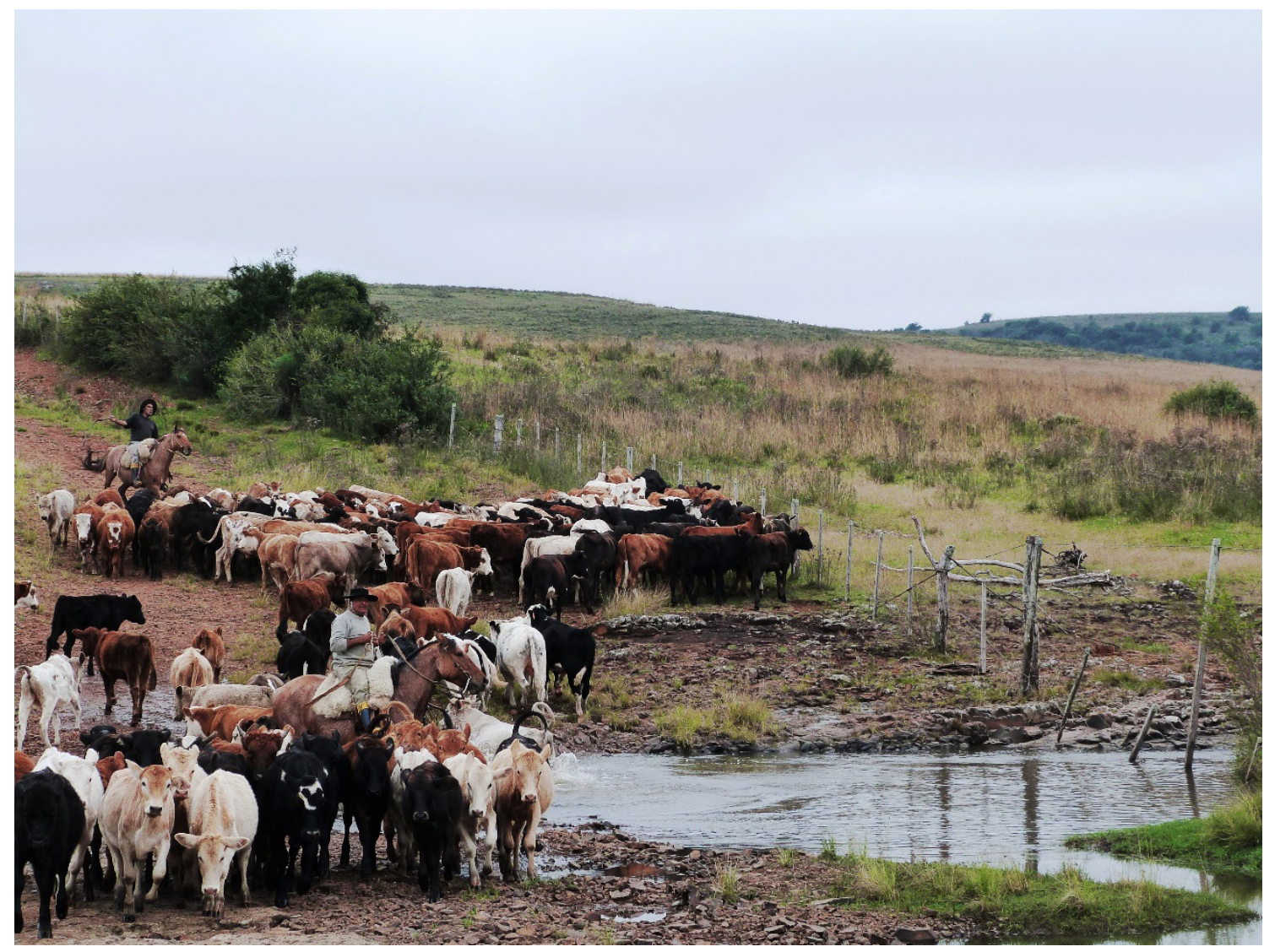

Figure 6: peões conducting a troop of cattle. Serra do Caverá, Rosário do Sul (Rio Grande do Sul, Brazil).

May 2014. Photo by the author.

As we saw in the previous section, by the disciplining the movement of herds through physical barriers inscribed on the surface of the landscape, the alambrado gradually rendered part of the campeiro workforce obsolete, in particular those tasked with capturing feral animals in open fields. It was against the sense of injustice instigated by this technical transformation that we must understand the peasant revolts against the alambrado in Argentina in the late 19th century (Beretta and Markoff 1978). Many of the contemporary gaúcho songs, which sing of rural flight and the ruin of traditional craft, are also nurtured by a melancholy caused by this same sense of injustice.

I mentioned earlier that one of the most common crimes in the Brazil-Uruguay border is cattle raiding. According to a survey carried out by Marlene Spaniol (2015), cattle raiding is the crime most commonly reported to the police in the region, accounting for 6o,16\% of crimes registered between 2012 and 2013 in Livramento (444 cases) and 67,4\% of crimes in Quaraí (122 cases). The precarious nature of rural roads, the lack of proper policing, and the demand for cheap meat on both sides of the border contribute to these statistics, which authorities treat as an "endemic" problem.

It is hence worth stressing that there exists a technical continuity between "legal" and "illegal" activities in Pampeano herding, since the same ethological knowledge and pastoral skills that are employed to care for cattle are also used to raid them. In this case too we can refer to positive direct and negative indirect actions of animal raiding or contraband: indeed, along the border, it is common for the alambrados to be lowered, so that cattle will cross the border line of their own accord. In this type of misdirection, it is not the human being who herds and forcibly conducts cattle out of the property, but the cows themselves who, perceiving the affordance (Gibson 1979; Reed 1988) of the lowered fence, follow their desired path. In a way, then, the cow becomes the agent of its own theft; all that humans have to do is to propitiate the environmental conditions under which this theft can take place. 


\section{Alambrados and alambradores in times of wild boars: new risks and new possibilities for action}

Recently, the Pampeano alambradores have started to experience a new type of risk in their countryside undertakings: attacks by wild boars. These animals were introduced into Argentina and Uruguay in the first decades of the zoth century, for breeding and hunting. They became feral and spread throughout the southern cone of South America, composing, along the way, hybrid populations with other types of pig, both wild and domestic (Lombardi et al., 2007). In Brazil, it seems as if the presence of wild boars is due both to spontaneous migration from Uruguay and Argentina and to isolated events of legal and illegal introduction of the animal in various parts of Brazil, in a process that began some three decades ago (Debert and Scherer, 2007). The region of the Ibirapuitã Area, which is only a few kilometres from one of the major points of dry-land transhumance in the Brazil-Uruguay border, emerged as one of the main vectors of animal penetration, as attested by the antiquity of the some of the reports I gathered during fieldwork.

Boars pose a risk to the alambradores who travel on foot, in small groups, across the countryside for long distances, and hence can run into females protecting their offspring or solitary males (cachaços) who can mortally wound a man with their sharp incisors. Since boars are nocturnal animals, chance encounters between alambradores and boars is attenuated by the daytime character of the former's activities. However, it is not uncommon for alambradores to run into large herds of feral pigs moving from one wooded area to another, or with cachaços resting in the woodland areas that sometimes lie in the path of new alambrados.

It is worth asking to what extent the proliferation of boars and the fear of encountering them has contributed to the decline of the alambrador trade, and the disinterest of younger people in the activity. As I have argued elsewhere (Sordi 2017; Sordi and Lewgoy 2017), however, the presence of boars in the fields of the south of Brazil are frequently a trope for evoking other problems that threaten the reproduction of a way of life tied to traditional herding, particularly that of the lack of a campeiro workforce, the replacement of areas of pasture for agricultural and agroforestry monocultures, as well as the presence of other exotic and invasive species such as the South African grass Eragrostis plana nees.

Nonetheless, the presence of boars has altered the material configuration of the fences. Many of the farmers of the Ibirapuitã Area have opted to electrify their mangueiras ('large corrals') and grazing areas, so as to keep wild pigs away from their herds and gardens. Likewise, the widespread belief that the appetite of feral pigs for newborn lambs will make sheep farming impossible in the long term leads many breeders to consider that the days of the seven-wire fence are numbered. In general, the fences have been deemed ineffective at containing the boars, which are able to nuzzle their way below the fences with ease. This evidently has an effect on the symbolic status of the alambrado as a material resonator of relations of property, resulting in many analogies and metaphors between the behaviour of wild pigs and the modus operandi of cattle raiders (Sordi e Lewgoy 2017).

In January 2013, the Ibama - Instituto Brasileiro do Meio Ambiente e dos Recursos Naturais Renováveis (Brazilian Institute for the Natural Environment and Renewable Natural Resources) - published a Normative Instruction allowing for the indefinite slaughter of boars throughout Brazil. Thus, the administrators of the Ibirapuitã Area, who are linked to the ICMBio - Instituto Chico Mendes de Preservação da Biodiversidade (Chico Mendes Institute for Bio-preservation) - forged an alliance with landowners and local amateur hunters who had already started to manage boar populations of their own accord, even if in an unofficial capacity.

One of the main points of negotiation between State agents and local hunters concerns which techniques should be used to capture the boars. State agents sought to inhibit forms of hunting that they saw as being excessively violent or inefficient from an ecological point of view. The administrators of the Ibirapuitã Area have thus tried to convince rural landowners to invest in the construction of cages and corral-traps to capture the animals through food lures, and to thereby prevent landowners from delegating managerial tasks to active chase groups; that is, to hunters who chase boars across open fields and corner them with the help of hounds. 
The corral-traps, also called encerra ('arrests') by analogy with the portals of livestock husbandry, consist of large and fixed capturing structures that are able to hold many animals at once. They are generally circular, constructed in a manner similar to the alambrados - that is, with wooden stakes, wire lines and screens. Needless to say, there remains a technical continuity between the knowledge and skill of the alambradores for raising traditional fencing, and those put into practice to construct corral-traps. Similarly, many structures originally built for alambrados, such as the mangueiras, have been actively transformed or adapted to trapping wild boars, conferring new uses on old structure and exploring new possibilities for action.

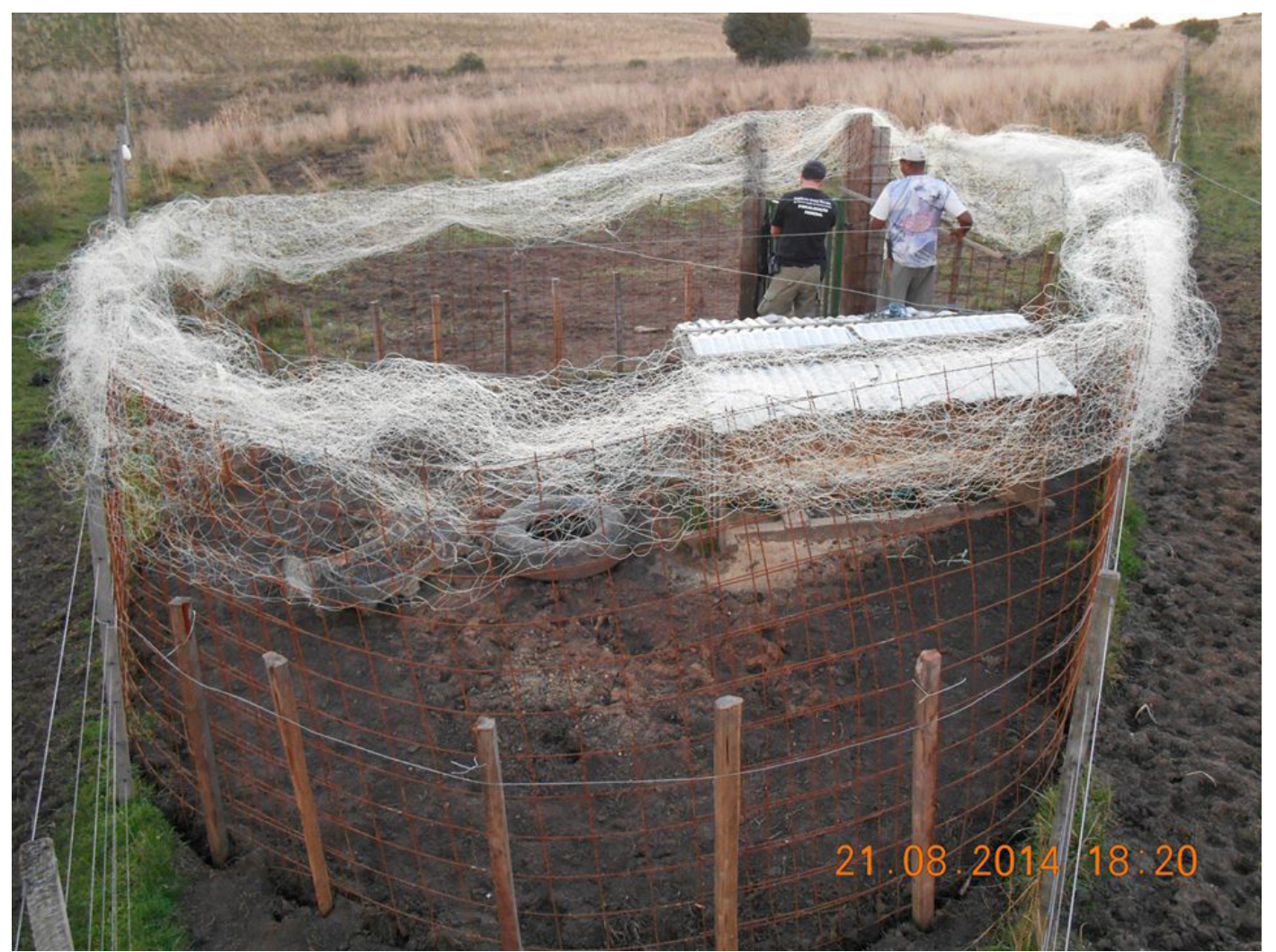

Figure 7: corral-trap for capturing wild boars which makes use of the corner of a former alambrado, Estância São Marcos, Rosário do Sul (Rio Grande do Sul, Brazil), August 2014. Photo: Ibirapuitã APA, ICMBio.

The preference of environmental managers for cages, however, is hardly consensual in the region, where many of the actors involved in management endorse the efficacy and pertinence of active chase strategies. Alongside the ecological-populational arguments put forward by these advocates, there is the evident support of hunting as a sportive activity that is constitutive of a rural, clientelist and masculine identity. As shown by Ortega y Gasset (2007), and developed by Marvin (2006, 2010), sportive hunters do not set out to kill prey, but rather kill prey for having set out on the hunt - that is, for having partaken of an intensive immersive experience in the wild, one which sharpens the sensory-perception and heightens the emotional excitement that accompany the chase and encirclement of wild animals

According to explanations frequently put forward by environmental managers, in contrast, the upkeep of fixed cages and traps is a good strategy for involving landowners with the management of wild boars, instead of delegating species control to often unknown hunters, interested in the sportive aspects of killing and capturing animals. It should be evident that this is evocative of the imaginary surrounding the theft of animals and other "illegal" activities intrinsically linked to the circulation of strangers through one's property, 
as discussed earlier. From a different angle, the dichotomy between a type of capture that is based on directly chasing the animal and another characterized by the manipulation of its Umwelt so as to facilitate its capture, recalls Marvin's (2006: 222) distinction between hunting by disturbance and hunting by disguise. As he observes:

Although each form of hunting has its own unique social and cultural shape and can be distinguished by its particular hunting practices, I would like to suggest that all forms of hunting can be divided in one of the two types according to the ways in which their practioners are present in the countryside. These I will define as hunting by disturbance and hunting by disguise, and in each category the relationship between the hunters and the prey are fundamentally different. In hunting by disturbance (...), the human presence in the natural world is clearly signaled and openly intrusive. In the case of hunting by disguise, the distinction between the human and the animal becomes blurred; the physical, behavioral, and emotional distance is closed.

As we can see, there is an approximation between, on the one hand, Marvin's (2006) distinction between hunting by disturbance and hunting by disguise, and, on the other, Haudricourt's (1962) notions of positive direct action and negative indirect action in relation to animals. Thus, just as the alambrados can be considered material resonators of the tension between the sedentary breeding and nomadic capture of cattle that has historically characterized Pampeano husbandry, the corral-traps and other fixed structures introduced by the agents of the ICMBio can also be interpreted as resonators of the negotiations between positive direct and negative indirect means of capturing boars, thereby reproducing, in the key of hunting, a set of asymmetrical relations and identity tensions that have long been a part of the pastoral world in the extreme south of Brazil.

As stressed by Bornholdt (2010, 2016), Beretta and Markoff (1978), and Pereira et al (2016), among others, the historical resistance of the campeiros to the more intensive methods of animal breeding - the start of which is marked by the emergence of the alambrados - is not a result of their simplicity, ignorance or aversion to the rational, but rather to their desire to retain a mode of subjectification and of the construction of masculinity that is necessarily tied to direct confrontation with animals and to shows of strength against natural elements. The same can be said of the support for the sportive hunt by advocates of the active chase. Through their rejection or mistrust of the corral-traps, they align themselves with a venatic subjectification which sees the boar as an opponent in a game, or as an adversary to be defeated in warfare, more than as a biological species to be managed.

\section{Concluding remarks}

In this article I have investigated the role of the alambrados and the alambradores who make them in the context of domestication and extensive herding developed in the Pampas of the Brazil-Uruguay border. To this end, I have used the concept of an "architecture of domestication" (Anderson et al. 2017) to draw attention to the importance of technical objects and environmental infrastructures in modulating and stabilizing the relations between humans and herd animals. By tracing the phylogenetic history and ontogenetic techniques of the alambrado, I have revealed its status as a "material resonator" (Lemonnier 2012) of the socioeconomic transformations that make up the Pampeano landscape and its set of human-animal relations, particularly the dichotomy between positive direct and negative indirect methods of animal rearing.

More specifically, I have underscored the importance of alambrados for the definition of "actors and spaces" (Akrich 1989) in the complex relational game that permeates daily life in the Pampas, even now, when pastoral activities are at a nadir. While, on the one hand, on the phylogenetic level, the fencing of open fields is an obstacle to a way of life and its associated skills, on the other, on the ontogenetic level, the knowledge associated with the construction, maintenance and use of the alambrados shows how new social configurations give rise to new skills and forms of existence, as well as different ways of relating to material things and the landscape. 
Without neglecting the tragic aspects of changes in the labour regime introduced by the fencing of fields, I see the alambrado as a marker of the historical emergence of another way of domesticating the agency of its human and other-than-human inhabitants, one which is closer to what Haudricourt (1962) classified as negative indirect action.

Finally, turning to the contemporary biological invasion stemming from the proliferation of wild boars and their hybrids in the region of the Plata River, I have stressed the technical continuities that exist between the more traditional world of cattle and sheep herding and the newer world of boar hunting, both of them made intelligible by a study of the physical structures that arrange space and the actions carried out by the beings that inhabit it. Through the existing tension between active chase hunting and the use of fixed traps, I have proposed that we find, in relations to wild boar, a mirror of the same conflicts that have structured the social relations in the Pampeano region for various decades; conflicts that occur against the backdrop of, on the one hand, the organization of territory through unequal relations of land ownership, and, on the other, the coexistence of distinct (if not antagonistic) relations between humans and animals.

By raising the hypothesis that there is an echo between the structural tensions of herding and hunting, we evidently disturb the very definition of what hunting is, and what, at the end of the day, distinguishes it from relations usually included under the label of "domestication". Is hunting a prelude to domestication? Is domestication a continuation of hunting in other terms? Is the difference between the two one of nature, of degree, or does it reflect an ethnocentric projection of western ways of classifying our relations with and to animals? This is, of course, a fascinating and contentious theme in anthropology (Ingold 1980; Descola 2002; 2005; Sautchuk 2016), to which this article has sought to contribute with historical and ethnographic data from a region in which these two worlds - cynegetic and pastoral - meet in a permanent state of contact, translation and friction.

Much like the idea of 'culture', the notion of 'domestication' possesses the paradoxical virtue of being, at once, a fundamental concept in anthropology and one which is permanently contested and asked to prove its heuristic use. In this article, I hope to have contributed not only to an understanding of the dynamic that gives form to the contemporary Pampeano taskscape (Ingold 2000), but, above all, to the more general development of an anthropology of domestication that can overcome its founding dichotomies, and provide new analytical instruments for understanding how humans and nonhumans build a common habitat. The anthropology of techniques, with its emphasis on the mediations made possible by technical objects and the gestures that animate them, seems to show us a fruitful way forward.

Received: August 15, 2018

Accepted: March 02, 2019

English version and proofreading: Luiz Costa 


\section{References}

AKRICH, Madeleine. 1987. “Comment décrire les objets techniques”. Techniques et Cultures, 9: 205-219.

ÁLVAREZ, Maria Fernanda T. 2011. “Tornar-se nativo / a resistência do liso”. In: Carlos A. Steil; Isabel C.M.

Carvalho (orgs.), Cultura, percepção e ambiente: diálogos com Tim Ingold. São Paulo: Terceiro Nome. pp. 153173 .

ANDERSON, David. 2014. "Cultures of reciprocity and cultures of control in the Circumpolar North". Journal of Northern Studies, 8(2): 11-27.

.; LOOVERS, Jan P.; SCHROER, Sara A.; WISHART, Robert P. 2017. "Architectures of domestication: on emplacing human-animal relations in the North". Journal of the Royal Anthropological Institute, 23(2): 398416.

BERETTA, Silvio R. D.; MARKOFF, John. 1978. "Civilization and Barbarism: cattle frontiers in Latin America". Comparative Studies in Society and History, 20(4): 587-620.

BORNHOLDT, Luciano. 2010. "Negociações desiguais: resistência na relação entre trabalhadores rurais e criadores de gado no Sul no Brasil”. Civitas, $10(3): 513-526$.

. 2016. Bigger than life: Cultural Identity and Labor Relations Among Gaucho Cowboys in Southern Brazil.

Arlington: Amakella Publishing.

BRASIL. IBGE. 200o. Censo demográfico. Avaliable at 〈www.ibge.gov.br〉. Access: em 25 de janeiro de 2019. . 2010. Censo demográfico. Avaliable at <www.ibge.gov.br>. Access: 25 de janeiro de 2019.

CRUZ, Rafael C.; GUADAGNIN, Demétrio L. 2010. "Uma pequena história ambiental do Pampa: proposta de uma abordagem baseada na relação entre perturbação e mudança”. In: Benhur P. da Costa; João Henrique Quoos; Maria E.G. Dieckel (orgs.), A sustentabilidade da Região da Campanha-RS: práticas e teorias a respeito das relações entre ambiente, sociedade, cultura e políticas públicas. Santa Maria: Programa de PósGraduação em Geografia e Geociências. pp. 154-178.

DA ROS, César Augusto. 2012. Terra e poder no Rio Grande do Sul: as políticas agrárias durante o governo Olivio Dutra (1999-2002). Rio de Janeiro: Garamond.

DEBERT, André Jean; SCHERER, Scherezino. 2007. "O javali asselvajado: ocorrência e manejo da espécie no Brasil". Natureza e Conservação, 5(2): 31-44.

DELEUZE, Gilles; GUATTARI, Félix. 1997. Mil Platôs: capitalismo e esquizofrenia. v. 5. São Paulo: Editora 34.

DESCOLA, Philippe. 2002. Genealogia de objetos e antropologia da objetivação. Horizontes Antropológicos, $8(18):$ 93-112.

. 2005. Par-delà nature et culture. Paris: Gallimard.

FARINATTI, Luís A. E. 2007. Confins Meridionais: familias de elite e sociedade agrária na fronteira sul do Brasil (1825-1865). Tese de Doutorado. Universidade Federal do Rio de Janeiro, Rio de Janeiro.

GELL, Alfred. 1996. “Vogel's net: traps as artworks and artworks as traps”. Journal of Material Culture, 1(1): 15-38.

GIBSON, James J. 1979. The ecological approach to visual perception. Boston: Houghton Mifflin.

GILLES, Tere J.; GEFU, Jerome. 1990. "Nomads, ranchers and the state: the sociocultural aspects of pastoralism. In: John G. Galaty; Douglas L. (orgs.), The world of pastoralism: herding systems in comparative perspective. London: Belhaven Press. pp. 99-118.

GOLIN, Tau. 1999. A Guerra Guaranítica: como os exércitos de Portugal e Espanha destruíram os Sete Povos dos Jesuitas e indios guaranis no Rio Grande do Sul. Passo Fundo: EdUPF.

HAUDRICOURT, André-Georges. 1962. "Domestication des animaux, culture des plantes et traitement d'autrui". L'Homme, 2(1): 40-50.

INGOLD, Tim. 1980. Hunters, Pastoralists and Ranchers: reindeer economies and their transformations. Cambridge: Cambridge University Press. 
2000. The Perception of the Environment: essays in livelihood, dwelling and skill. London: Routledge. . 2011. Being Alive: essays on movement, knowledge and perception. Routledge: London.

LEACH, Helen M. 2007. "Selection and the Unforeseen Consequences of

Domestication”. In: Rebecca Cassidy; Molly Mullin (eds.), Where the wild things are now: domestication reconsidered. New York: Berg. pp. 71-100.

LEMONNIER, Pierre. 2012. Mundane objects: materiality and non-verbal communication. Walnut Creek, California: Left Coast Press.

LOMBARDI, R.; BERRINI, R.; ACHAVAL, R.; WAYSON, C. 2007. El Jabali en el Uruguay. Montevideo: Centro Interdisciplinario para el Desarollo.

LOPES NETO, João Simões. 1976. “Correr eguada”. In: Contos gauchescos. 9a ed. Porto Alegre: Globo.

MARVIN, Garry. 2006. "Wild killing: contesting the animal in hunting”. In: The Animal Studies Group. Killing animals. Chicago: University of Illinois Press. pp. 10-29.

. 2010. "Challenging animals: project and process in hunting". In: Sarah Pilgrim; Jules Pretty (eds.),

Nature and Culture. London: Earthscan. pp. 145-162.

MARTÍNEZ-ESTRADA, Ezequiel. 2017. Radiografía de la Pampa. Buenos Aires: Interzona.

NAHUM, Benjamin. 1968. “La estancia alambrada”. In: Enciclopedia Uruguaya, v. 24. Montevideo: Editores Reunidos.

NEUMANN, Eduardo. 2000. "Fronteira e identidade: confrontos luso-guarani na Banda Oriental 1680-1757". Revista Complutense de Historia de América, 26: 73-92.

ORTEGA Y GASSET, José. 2007. “Sobre la caza - prologo a 'Veinte años de caza mayor', del Conde de Yebes [1943]”. In: Sobre la caza, los toros y el toreo. Madrid: Alianza Editorial. pp. 145-163.

OSÓRIO, Helen. 2006. "Rebanhos, searas e roças. Uma aproximação à paisagem agrária do Rio Grande de São Pedro no período colonial". Ciência \& Ambiente, 33: 121-133.

PEREIRA, Fabíola M.; RIETH, Flávia M.S.; KOSBY, Marília. 2016. "Inventário Nacional de Referências Culturais - Pecuária, Bagé/RS”. In: Ciméa B. Bevilaqua; Felipe Vander Velden (orgs.), Parentes, vítimas, sujeitos: perspectivas antropológicas entre humanos e animais. São Carlos: EdUFSCar; Curitiba: Editora UFPR. pp. 189-206.

REED, Edward S. 1988. "The affordances of the animate environment: social science from the ecological point of view". In: Tim Ingold (org.), What is an animal? London: Routledge. pp 110-126.

RUSSELL, Nerissa 2007. "The domestication of anthropology”. In: Rebecca Cassidy; Molly Mullin (eds.), Where the wild things are now: domestication reconsidered. New York: Berg. pp. 27-48.

SARMIENTO, Domingo F. 2010. Facundo: civilização e barbárie. São Paulo: Cosac Naify.

SAUTCHUK, Carlos E. 2016. "Eating (with) piranhas: untamed approaches to domestication". Vibrant, 13(2): 38-57.

SEGATA, Jean. 2017. “O Aedes Aegypti e o digital”. Horizontes Antropológicos, 23(48): 19-48.

SORDI, Caetano. 2015. "Guerra ao javali: invasão biológica, feralização e domesticação nos campos sulinos". R@U: Revista de Antropologia da UFSCar, 7: 59-77.

. 2017. Presenças ferais: Invasão biológica, javalis asselvajados (Sus scrofa) e seus contextos no Brasil Meridional em perspectiva antropológica. Tese de Doutorado, Universidade Federal do Rio Grande do Sul.

.; LEWGOY, Bernardo. 2017. "Boars in the Pampas: biological invasions, cattle rustling and landscape transformations in the Brazilian-Uruguayan border”. Horizontes Antropológicos, 48: 75-98.

SPANIOL, Marlene Inês. 2015. "(Re)estruturação das ações de segurança pública, prevenção, repressão e controle, através da Enafron, ante as principais incidências criminais na fronteira Brasil-Uruguai”. In: Maria I. Mallmann; Teresa C. Marques (orgs.), Fronteiras e relações: Brasil-Uruguai. Porto Alegre: Edipucrs. pp. 183-198. 
STÉPANOFF, Charles; VIGNE, Jean-Denis. 2019. “Introduction”. In: Charles Stépanoff; Jean-Denis Vigne (eds.), Hybrid communities: biosocial approaches to domestication and other trans-species relationships. London: Routledge. pp. 1-20.

STOECKLI, Pedro. 2017. "A brutidade entre vaqueiros e búfalos no Baixo Araguari - Amapá". Horizontes Antropológicos, 23(48): 171-196.

XAVIER, Paulo. 1964. “A estância no Rio Grande do Sul”. In: Rio Grande do Sul: terra e povo. Porto Alegre: Globo. pp. 55-69.

WILSON, Peter J. 2007. "Agriculture or architecture? The beginnings of domestication”. In: Rebecca Cassidy; Molly Mullin (eds.), Where the wild things are now: domestication reconsidered. New York: Berg. pp. 101-122.

\section{Caetano Sordi}

National Institute of Historic and Artistic Heritage (IPHAN), Porto Alegre/RS, Brazil https://orcid.org/oooo-0003-2334-8096

Author's email: caetano.sordi@gmail.com 